\title{
Field efficacy of formulation of fungal bioagents against bacterial leaf blight of rice caused by Xanthomonas oryzae pv. oryzae (Uyeda and I shiyama) Dowson
}

\section{Gokil Prasad Gangwar}

Department of Plant Pathology, G. B. Pant University of Agriculture and Technology, Pantnagar, 263 145, INDIA

E-mail: gokil_prasad@rediffmail.com

Received: September 11, 2013; Revised received: October 3, 2013; Accepted: October 5, 2013

\begin{abstract}
In the present study, Trichoderma harzianum, T. hamatum, T. virens and three isolates of Trichoderma spp. were evaluated for their comparative efficacy against bacterial leaf blight of rice, under field conditions. All the bioagent formulations were significantly effective in reducing disease severity over check during Kharif season 2006 and 2007. T. harzianum was found to be most effective and resulted 48.26 and $59.22 \%$ reduction in disease severity during Kharif season 2006 and 2007, respectively. Maximum increase in grain yield (16.21\%) was recorded with T. harzianum followed by isolate $40(14.58 \%)$, during Kharif season 2006 . Whereas during Kharif season 2007, maximum increase in grain yield (18.95\%) was recorded with T. harzianum which is followed by T. virens (14.65\%) and isolate $40(12.57 \%)$. Present study revealed that T. harzianum (isolated from rice phylloplane) was found to be most effective in reducing disease severity and increasing grain yield as compared to other isolates obtained from different sources.
\end{abstract}

Keywords: Bacterial leaf blight of rice, Field efficacy, Trichoderma hamatum, Trichoderma harzianum, Trichoderma virens, Xanthomonas oryzae pv. oryzae,

\section{INTRODUCTION}

Bacterial leaf blight of rice caused by Xanthomonas oryzae pv. oryzae is the disease of great economic importance in all rice growing areas of the world and is particularly destructive in South East Asia during the heavy rains of monsoon season (Mew et al., 1993). Nonavailability of effective chemical control measures and inconsistent performance of resistant rice varieties have forced the plant pathologists to look for new approaches of disease management (Buddenhagen, 1983; Kaul \& Sharma, 1987; Mew, 1987). Interest in biological management has increased considerably in the recent past due to their added advantage over the other methods of plant disease management (Whipps and Mequilken, 1993; Dube, 1995; Pankhurst and Lynch, 1995). The microbial antagonists occurs in nature are host specific, virulent, self perpetuating and genetically stable. Hence, biological control has emerged an alternative and most promising means of the management of plant pathogens. Many workers reported the effectivity of Trichoderma spp., T. harzianum, T. hamaum and T. virens (Manmeet and Thind, 2002; Nzojiyobiri et al., 2003; Gangwar and Sinha, 2010a,b; Gangwar and Sinha, 2012a,b) and phylloplane microflora (Sindhan et al., 1997) against X. oryzae pv. oryzae causing bacterial leaf blight disease in rice.

Trichoderma harzianum, T. hamatum, T. virens and 49 isolates of Trichoderma spp. (isolated from different sources and locations) were screened for comparative antagonistic potential against $X$. oryzae pv oryzae $\left(X_{00}\right)$ in vi tro (Gangwar and Sinha, 2010a; Gangwar and Sinha, 2012a) and ten potential fungal bioagents (seven isolates of Trichoderma spp. and T. harzianum, T. hamatum and $T$. virens) were selected for their evaluation against bacterial leaf blight of rice, under glass house conditions (Gangwar and Sinha, 2012b). Among these, six potential fungal bioagents were selected for testing field efficacy against bacterial leaf blight of rice. In the present study, these six potential bioagents were evaluated for their comparative efficacy against bacterial leaf blight of rice, under field conditions.

\section{MATERIALS AND METHODS}

In the present study, comparative efficacy of six potential fungal bioagants viz. Trichoderma harzianum, $T$. hamatum and T. virens and three isolates of Trichoderma spp. (isolate 25, 31 and 40) which were isolated from different sources (Table 1) were tested against bacterial leaf blight of rice, under field conditions.

$M$ ass multiplication of fungal bioagents and preparation of formulation: The fungal bioagents were mass multiplied on barnyard millet (E chinocloa frumentacae). Grains colonized by Trichoderma spp. were air dried in open shade and ground with the help of Willy Mill to get fine powder. This powder was passed through 50 and 80 
mesh sieves simultaneously to obtain spore powder and diluted with talcum powder $($ mesh $=350$ with $95 \%$ whiteness) and $1 \%$ carboxyl methyl cellulose (CMC) to get desired concentration $\left(10^{6} \mathrm{cfu} / \mathrm{g}\right)$.

Field experiment: The experiment was carried out in Kharif season during the year 2006 and 2007 at Crop Research Center, G. B. Pant University of Agriculture and Technology, Pantnagar using randomized block design (RBD). Topographically, Pantnagar is located at $29^{\circ} \mathrm{N}$ latitude, $79.3^{\circ} \mathrm{E}$ longitude and at an altitude of 243.84 meter above the mean sea level in the humid and subtropical regions of North West Plain Zone at the foothills of Shivalik range of Himalayas. The average relative humidity was highest (70-90\%) in July-August and December-January and lowest (35-40\%) in April-May. Susceptible rice cultivar Jaya was used for the experiment. General agronomic practices were followed for cultivation of experimental plots. Pathogen was inoculated at maximum tillering stage by clipping off the leaf tip @ $10^{6}$ cell/ml inoculum (Kauffman et al., 1973).

A pplication of treatments: Formulations of fungal bioagents were applied @ $10 \mathrm{~g} / \mathrm{l}$ as foliar spray next day of inoculation of pathogen in the evening hours to avoid exposure to hot sunshine. Two foliar sprays of bioagents formulations and chemical treatments were given at one week interval. Check plots were sprayed with sterilized water. Each treatment was replicated thrice.

Data collection: Data was recorded as percent disease severity on artificially inoculated leaves (average 50 leaves/plot) at 14, 21 and 28 days after treatment application. After harvesting yield components (number of filled and unfilled grains per plants, grain yield and 1000 grain weight) were recorded.

Statistical analysis: Statistical analysis of the data obtained from field experiment was done using appropriate programme as per the requirement of the experiment. The critical difference (CD) was calculated at $5 \%$ level of significance for comparison of difference between the means of different treatments.

\section{RESULTS}

Effect of fungal bioagent formulations on disease severity: All the isolates of Trichoderma spp. significantly reduced disease severity of bacterial leaf blight over check during K harif season 2006 and 2007 (Table 2). During K harif season 2006 T. harzianum was found most effective and exhibited 48.26 per cent reduction in disease severity. Foliar spray with isolate 31 , isolate 40 and $T$. virens was next in order to effectivity and exhibited $47.91 \%$ reduction in disease severity. During K harif season 2007 T. harzianum resulted in maximum reduction (59.22\%) in disease severity followed by isolate $25(57.97 \%)$.

Effect of fungal bioagent formulations on number of filled grains per plant: All the isolates of Trichoderma spp. were significantly effective in increasing number of filled grains per plant over check during K harif season 2006 and 2007 (Table 3). The highest increase (36.84\%) in number of filled grains was obtained with $\mathrm{T}$. harzianum followed by isolate $40(24.90 \%)$ and T. virens $(23.87 \%)$ during K harif season 2006. During K harif season 2007, maximum increase $(29.71 \%$ ) in number of filled grains was obtained with $\mathrm{T}$. harzianum followed by $\mathrm{T}$. virens and isolate 31 which resulted in increase in number of filled grains per plant by 26.22 and 19.49 per cent, respectively. E ffect of for mulation of fungal bioagents on grain yield and 1000 grain weight: The data obtained on the effect of Trichoderma spp. in increasing grain yield and 1000 grain weight was significantly higher over check during Kharif season 2006 and 2007 (Table 3). Maximum increase in grain yield $(16.21 \%)$ was recorded with T. harzianum followed by isolate $40(14.58 \%)$ during Kharif season 2006. Maximum increase (33.00\%) in 1000 grain weight was observed with T. harzianum which is followed by T. hamatum (32.15\%). During K harif season 2007, Maximum increase in grain yield $(18.95 \%)$ was recorded with $\mathrm{T}$. harzianum application followed by T. virens $(14.65 \%)$ and isolate $40(12.57 \%)$. Maximumincrease in 1000 grain weight was recorded with T. hamatum (54.44\%) which is followed by T. virens (50.67\%) and T. harzianum (50.55\%).

\section{DISCUSSION}

In the present investigation, six fungal bioagent formulations were evaluated against bacterial leaf blight disease of rice during $\mathrm{K}$ harif season during the year 2006 and 2007. T. harzianum (rice leaf isolate) was found most effective in reducing disease severity and increasing grain yield. Trichoderma spp. (isolate 40) and T. virens were found next in order of effectivity in reducing disease severity and increasing the grain yield. This indicates that fungal bioagents could proliferate and establish on rice host surface which resulted in reduction in bacterial blight disease severity. Similar results were observed in glasshouse studies carried by Gangwar and Sinha, (2012b). Higher effectivity of Trichoderma isolates obtained from rice phylloplane against bacterial leaf blight

Table 1. List of fungal bioagents isolated from different sources.

\begin{tabular}{ll}
\hline $\begin{array}{l}\text { I solates of } \\
\text { Trichoderma spp. }\end{array}$ & Sources \\
\hline Isolate 31 & Soil of rice field \\
Isolate 25 & Soil of rice field \\
Isolate 40 & Soil of rice field \\
T. harzianum & Rice phylloplane \\
T. virens & Rice phylloplane \\
T. hamatum & Rice phylloplane \\
\hline
\end{tabular}


Table 2. Efficacy of Trichoderma spp. on disease severity of bacterial leaf blight applied as foliar spray, under field condition during K harif season 2006 and 2007.

\begin{tabular}{|c|c|c|c|c|c|c|}
\hline \multirow[b]{3}{*}{ Treatments } & \multicolumn{6}{|c|}{ Disease severity (\% ) } \\
\hline & \multicolumn{3}{|c|}{ Kharif season 2006} & \multicolumn{3}{|c|}{ K harif season 2007} \\
\hline & $\begin{array}{c}14 \text { days } \\
\text { After first } \\
\text { spray }\end{array}$ & $\begin{array}{c}21 \text { days } \\
\text { After first } \\
\text { spray }\end{array}$ & $\begin{array}{c}28 \text { days } \\
\text { After fir st } \\
\text { spray }\end{array}$ & $\begin{array}{c}14 \text { days } \\
\text { After fir st } \\
\text { spray }\end{array}$ & $\begin{array}{c}21 \text { days } \\
\text { A fter first } \\
\text { spr ay }\end{array}$ & $\begin{array}{c}28 \text { days } \\
\text { A fter first } \\
\text { spray }\end{array}$ \\
\hline Isolate 31 & $\begin{array}{c}15.33 \\
(23.03)\end{array}$ & $\begin{array}{c}47.33 \\
(43.46)\end{array}$ & $\begin{array}{c}50.00 \\
(44.99)\end{array}$ & $\begin{array}{c}17.33 \\
(24.57)\end{array}$ & $\begin{array}{c}27.00 \\
(31.30)\end{array}$ & $\begin{array}{c}40.00 \\
(39.22)\end{array}$ \\
\hline Isolate 25 & $\begin{array}{c}17.00 \\
(24.33)\end{array}$ & $\begin{array}{c}52.33 \\
(46.33)\end{array}$ & $\begin{array}{c}53.33 \\
(46.91)\end{array}$ & $\begin{array}{c}17.66 \\
(24.83)\end{array}$ & $\begin{array}{c}27.66 \\
(31.72)\end{array}$ & $\begin{array}{c}38.66 \\
(38.44)\end{array}$ \\
\hline Isolate 40 & $\begin{array}{c}15.33 \\
(23.04)\end{array}$ & $\begin{array}{c}48.00 \\
(43.84)\end{array}$ & $\begin{array}{c}50.00 \\
(44.99)\end{array}$ & $\begin{array}{c}17.66 \\
(24.78)\end{array}$ & $\begin{array}{c}28.00 \\
(31.92)\end{array}$ & $\begin{array}{c}42.66 \\
(40.78)\end{array}$ \\
\hline T. harzianum & $\begin{array}{c}13.83 \\
(21.79)\end{array}$ & $\begin{array}{c}41.66 \\
(40.19)\end{array}$ & $\begin{array}{c}49.66 \\
(44.81)\end{array}$ & $\begin{array}{c}15.00 \\
(22.73)\end{array}$ & $\begin{array}{c}25.33 \\
(30.21)\end{array}$ & $\begin{array}{c}37.51 \\
(37.76)\end{array}$ \\
\hline T. virens & $\begin{array}{c}16.66 \\
(23.96)\end{array}$ & $\begin{array}{c}45.00 \\
(42.12)\end{array}$ & $\begin{array}{c}50.00 \\
(44.99)\end{array}$ & $\begin{array}{c}16.00 \\
(23.55)\end{array}$ & $\begin{array}{c}25.66 \\
(30.43)\end{array}$ & $\begin{array}{c}39.66 \\
(39.03)\end{array}$ \\
\hline T. hamatum & $\begin{array}{c}15.66 \\
(23.28)\end{array}$ & $\begin{array}{c}49.00 \\
(44.41)\end{array}$ & $\begin{array}{c}58.33 \\
(49.83)\end{array}$ & $\begin{array}{c}16.66 \\
(24.08)\end{array}$ & $\begin{array}{c}27.00 \\
(31.29)\end{array}$ & $\begin{array}{c}41.00 \\
(39.78)\end{array}$ \\
\hline Check & $\begin{array}{c}21.00 \\
(27.25)\end{array}$ & $\begin{array}{c}66.66 \\
(54.83)\end{array}$ & $\begin{array}{c}96.00 \\
(78.67)\end{array}$ & $\begin{array}{c}21.00 \\
(27.23)\end{array}$ & $\begin{array}{c}41.66 \\
(40.20)\end{array}$ & $\begin{array}{c}92.00 \\
(73.82)\end{array}$ \\
\hline $\mathrm{CD}$ at $5 \%$ & ns & 10.43 & 8.77 & 3.20 & 2.78 & 6.17 \\
\hline
\end{tabular}

*Mean of three replications; Values in parenthesis are angular transformed

Table 3. Efficacy of Trichoderma spp. on number of filled and unfilled grains per plant, grain yield and 1000 grain weight applied as foliar spray, under field condition during K harif season 2006 and 2007.

\begin{tabular}{|c|c|c|c|c|c|c|}
\hline \multirow{2}{*}{ Treatments } & \multicolumn{2}{|c|}{ No. of filled grains/ plant } & \multicolumn{2}{|c|}{ Grain yield $(q / h)$} & \multicolumn{2}{|c|}{1000 grain weight $(\mathrm{g})$} \\
\hline & 2006 & 2007 & 2006 & 2007 & 2006 & 2007 \\
\hline Isolate 31 & 2246 & 2213 & 26.09 & 26.32 & 25.63 & 24.90 \\
\hline Isolate 25 & 2242 & 2181 & 26.20 & 24.74 & 25.53 & 24.48 \\
\hline Isolate 40 & 2297 & 2051 & 26.81 & 26.68 & 25.64 & 24.30 \\
\hline T. harzianum & 2517 & 2403 & 27.19 & 28.19 & 26.11 & 25.29 \\
\hline T. virens & 2278 & 2338 & 25.60 & 27.17 & 25.31 & 25.31 \\
\hline T. hamatum & 2160 & 2056 & 25.67 & 24.99 & 25.94 & 25.94 \\
\hline Check & 1839 & 1852 & 23.40 & 23.70 & 19.63 & 16.85 \\
\hline $\mathrm{CD}$ at $5 \%$ & 218 & 225 & 2.41 & 2.13 & 2.94 & 2.68 \\
\hline
\end{tabular}

*Mean of three replications

pathogen was reported by Gangwar and Sinha, (2012a). T. harzianum also found highly effective against bacterial blight pathogen $X$. oryzae pv. oryzae under in vitro screening (Gangwar and Sinha, 2010a; Gangwar and Sinha, 2012a). Evaluation of different antagonists for control of bacterial leaf blight pathogen in the field was carried out by Manmeet and Thind (2002) which revealed that significant reduction in the disease intensity was observed by T. harzianum application.

\section{Conclusion}

Present study revealed that efficacy of different Trichoderma spp. and isolates against bacterial leaf blight rice was varied. T. harzianum (isolated from rice phylloplane) was found to be most effective in reducing disease severity and increasing grain yield as compared to other isolates obtained from different sources. The observed results should be verified on large scale rice planting.

\section{REFERENCES}

Buddenhagen, I.W. (1983). Disease resistance in rice. In: Durable resistance in crops (Ed. by Lamberti, F.; Waller, J.M.; Graaff, N.A. van der), pp. 401-428. Plenum, New York, USA.

Dube, H.C. (1995). Rhizobacteria in the biological control of plant diseases. In : J., P., Verma, A., Verma, D. Kumar (eds.), Detection of Plant pathogens and their management. Ankor Publishers (Ltd.), New Delhi, 139-152.

Gangwar, G. P. and Sinha, A. P. (2012b). Evaluation of Trichoderma spp. and fluorescent pseudomonads for the management of bacterial leaf blight of rice. Indian Phytopath., 65 (1): 89-91.

Gangwar, G.P. and Sinha, A.P. (2010a). Comparative antagonistic potential of Trichoderma spp. against 
Xanthomonas oryzae pv. oryzae. Ann. PI. Protec. Sci., 18(2): 458-463.

Gangwar, G.P. and Sinha, A.P. (2010b). Effect of rate of application of fungal and bacterial antagonists on bacterial leaf blight of rice. Agric. Sci. Digest., 30 (1): 54-56.

Gangwar, G.P. and Sinha, A.P. (2012a). Comparative antagonistic potential of fungal and bacterial bioagents against isolates of Xanthomonas oryzae pv. oryzae. Ann. PI. Protec. Sci., 20 (1): 154-159.

Kauffman, H.E., Reddy, A.P. K., Heisk, S.P.V. and Maraca, S.D. (1973). An improved technique for evaluating resistance of rice varieties to Xanthomonas oryzae. Plant D is. Rep., 57: 537-541.

Kaul, M.L.H. and Sharma, K.K (1987). Bacterial blight of rice - a review. Biologisches Zentralblatt 106, 141-167.

Manmeet, M. and Thind, B.S. (2002). Management of bacterial blight of rice with bioagents. Plant D is. Res., 17(1): 21-28.

Mew, T.W. (1987). Current status and future prospects of research on bacterial blight of rice. Annual Review of Phytopathology 25, 359-382.

Mew, T.W., Alvarez, A.M., Leach, J.E. and Swings, J. (1993). Focus on bacterial blight of rice. Plant Dis., 77(1): 5-12.

Nzojiyobiri, J.B., Xu, T., Song, F.M. and Shen, Y. (2003). Resistance induced by Trichoder ma harzianum NF9 against $M$ agnaporthe grisea and Xathomonas oryzae pv. oryzae in rice. Chinese J ournal of Biological Control, 19(3): 111-114. Pankhurst, C.E. and Lynch, J.M. (1995). The role of soil microbiology in sustainable intensive agriculture, Advances in Plant Pathology. Vol. II. Academic Press Ltd. pp. 229-247.

Sindhan, G.S., Parasher, R.D. and Hooda, I. (1997). Biological control of bacterial leaf blight of rice caused by Xanthomonas oryzae pv. oryzae. Plant Dis. Res., 12(1): 29-32.

Whipps, J.M. and Mequilken, M.P. (1993). Aspects of biocontrol of fungal pathogens. In: Jones, D.G. (ed.), Exploitation of microorganism. Champman and Hall London. pp. 45-79. 